\title{
Peringkasan Teks Otomatis Berita Berbahasa Indonesia Menggunakan Metode Maximum Marginal Relevance
}

\author{
Muchammad Mustaqhfiri ${ }^{1}$, Zainal Abidin ${ }^{2}$ dan Ririen Kusumawati ${ }^{3}$ \\ Jurusan Teknik Informatika, Fakultas Sains dan Teknologi \\ Universitas Islam Negeri Maulana Malik Ibrahim Malang \\ Email: ${ }^{1}$ admust86@gmail.com, ${ }^{2}$ zainal@ti.uin-malang.ac.id dan \\ 3rizn.kusumawati@gmail.com
}

\begin{abstract}
Abstrak-Perkembangan teknologi internet berdampak bertambahnya jumlah situs berita berbahasa Indonesia dan menciptakan ledakan informasi. Hal tersebut menuntut semua informasi bisa diakses dengan cepat dan tidak harus membutuhkan banyak waktu dalam membaca sebuah headline berita.Teknologi peringkas teks otomatis menawarkan solusi untuk membantu pencarian isi berita berupa deskripsi singkat (summary). Penelitian diawali dengan lima tahap text preprocessing: pemecahan kalimat,case folding, tokenizing, filtering, dan stemming. Proses selanjutnya menghitung bobot tf-idf, bobot query relevance dan bobot similarity. Ringkasan dihasilkan dari ekstraksi kalimat dengan menggunakan metode maximum marginal relevance. Metode ekstraksi maximum marginal relevance merupakan metode yang digunakan untuk mengurangi redudansi dalam perangkingan kalimat pada multi dokumen. Data uji coba diambil dari surat kabar berbahasa Indonesia online sejumlah 30 berita. Hasil pengujian dibandingkan dengan ringkasan manual yang menghasilkan rata-rata recall $60 \%$, precision $77 \%$, dan f-measure $66 \%$.
\end{abstract}

Kata kunci: peringkasan, text preprocessing, $t f$-idf, query relevance, similarity, maximum marginal relevance

\section{PENDAHULUAN}

Membaca merupakan bagian dari kebutuhan manusia, baik membaca buku, surat kabar, dan majalah. Perkembangan teknologi komunikasi berdampak pada penggunaan internet untuk mempublikasi artikel di situs-situs di internet. Demikian juga dengan artikel-artikel berita, berita banyak yang diunggah di situs-situs surat kabar on-line.

Ringkasan dibutuhkan untuk mendapatkan isi artikel secara ringkas. Ringkasan merupakan ekspresi yang ketat dari isi utama suatu artikel, tujuannya untuk memberitahu pada pembaca inti dari suatu pikiran utama (Sartuni, Finoza dan Sundari, 1984:97). Konsep sederhana ringkasan adalah mengambil bagian penting dari keseluruhan isi dari artikel. Menurut Mani dan Maybury, ringkasan adalah mengambil isi yang paling penting dari sumber informasi yang kemudian menyajikannya kembali dalam bentuk yang lebih ringkas bagi penggunanya (Mani dan Maybury, 1999). Aplikasi peringkasan teks otomatis merupakan teknologi yang menawarkan solusi untuk mencari informasi dengan menghasilkan ringkasan (summary) berita.

\section{TINJAUAN PUSTAKA}

\subsection{Peringkasan Teks Otomatis}

Peringkasan teks otomatis (automatic text summarization) adalah pembuatan bentuk yang lebih singkat dari suatu teks dengan memanfaatkan aplikasi yang dijalankan dan dioperasikan pada komputer. Sedangkan menurut Hovy, ringkasan adalah teks yang dihasilkan dari sebuah teks atau banyak teks, yang mengandung isi informasi dari teks asli dan panjangnya tidak lebih dari setengah panjang teks aslinya (Hovy, 2001). 
Penelitian peringkasan teks otomatis dipelopori oleh Luhn sejak tahun 1958. Teknik-teknik yang digunakan dalam peringkasan: (1) teknik pendekatan statistika: teknik word frequency (Luhn, 1958), position in text (Baxendale, 1958), cue words and heading (Edmudson, 1969), sentence position (Lin dan Hoovy, 1997), (2) teknik pendekatan dengan natural language analysis: inverse term frequency and NLP technique (Aone, 1990), lexical chain (Mc Keown, 1997), maximal marginal relevance (Cabonell dan Goldstein, 1998).

\subsection{Maximum Marginal Relevance}

Algoritma maximum marginal relevance $(M M R)$ merupakan salah satu metode ekstraksi ringkasan (extractive summary) yang digunakan untuk meringkas dokumen tunggal atau multi dokumen. $M M R$ meringkas dokumen dengan menghitung kesamaan (simlarity) antara bagian teks.

Pada peringkasan dokumen dengan metode $M M R$ dilakukan proses segmentasi dokumen menjadi kalimat dan dilakukan pengelompokan sesuai dengan gender kalimat tersebut. $M M R$ digunakan dengan mengkombinasikan matrik cosine similarity untuk merangking kalimat-kalimat sebagai tanggapan pada query yang diberikan oleh user.

Kebanyakan mesin pencarian information retrieval (IR) modern menghasilkan daftar perangkingan dari dokumen yang diukur dari penurunan relevansi terhadap permintaan user (user query). Penaksiran pertama untuk mengukur hasil peringkasan yang relevan adalah dengan mengukur hubungan antar informasi yang ada dalam dokumen dengan query yang diberikan oleh user dan menambah kombinasi linier sebagai sebuah matrik. Kombinasi linier ini disebut "marginal relevance" (Carbonell dan Goldstein, 1998).

Sebuah dokumen dikatakan mempunyai marginal relevance yang tinggi jika dokumen tersebut relevan terhadap isi dari dokumen dan mempunyai kesamaan bobot term maksimum dibandingkan dengan query. Peringkasan dokumen dengan tipe ekstraktif, nilai akhir diberikan pada kalimat $\mathrm{S}_{\mathrm{i}}$ dalam $M M R$ dihitung dengan persamaan 1 .

MMR $=\operatorname{argmax}\left[\lambda * \operatorname{Sim}_{1}\left(S_{i}, Q\right)-(1-\lambda) * \max \operatorname{Sim}_{2}\left(S_{i}, S^{\prime}\right)\right]$

$S_{i}$ adalah kalimat di dokumen, sedangkan $S$ ' adalah kalimat yang telah dipilih atau telah diekstrak (Shasha Xie, 2010). Koefisien $\lambda$ digunakan untuk mengatur kombinasi nilai untuk memberi penekanan bahwa kalimat tersebut relevan dan untuk mengurangi redudansi. Pada penelitian ini, Sim1 dan Sim2 merupakan dua fungsi similarity yang merepresentasikan kesamaan kalimat pada seluruh dokumen dan memilih masing-masing kalimat untuk dijadikan ringkasan. Siml adalah matrik similarity kalimat $S_{i}$ terhadap query yang diberikan oleh user sedangkan Sim2 adalah matrik similarity kalimat $S_{i}$ terhadap kalimat yang telah diekstrak sebelumnya (Shasa Xie, 2010).

Nilai parameter $\lambda$ adalah mulai dari 0 sampai dengan 1 (range [0,1]). Pada saat parameter $\lambda=1$ maka nilai $M M R$ yang diperoleh akan cenderung relevan terhadap dokumen asal. Ketika $\lambda=0$ maka nilai $M M R$ yang diperoleh cenderung relevan terhadap kalimat yang diekstrak sebelumnya. Oleh sebab itu sebuah kombinasi linier dari kedua kriteria dioptimalkan ketika nilai $\lambda$ terdapat pada interval $[0,1]$. Untuk peringkasan small dokumen, seperti pada berita (news), menggunakan nilai parameter $\lambda=0.7$ atau $\lambda=0.8$, karena akan menghasilkan ringkasan yang baik (Jade Goldstein, 2008).

Untuk mendapatkan hasil ringkasan yang relevan maka harus menetapkan nilai $\lambda$ ke nilai yang lebih dekat dengan $\lambda$. Kalimat dengan nilai $M M R$ yang tertinggi akan dipilih berulang kali ke dalam ringkasan sampai tercapai ukuran ringkasan yang diinginkan. 


\subsection{Cosine Similarity}

Cosine similarity digunakan untuk menghitung pendekatan relevansi query terhadap dokumen. Penentuan relevansi sebuah query terhadap suatu dokumen dipandang sebagai pengukuran kesamaan antara vektor query dengan vektor dokumen. Semakin besar nilai kesamaan vektor query dengan vektor dokumen maka query tersebut dipandang semakin relevan dengan dokumen. Saat mesin menerima query, mesin akan membangun sebuah vektor $\mathrm{Q}\left(\mathrm{w}_{\mathrm{q} 1}, \mathrm{w}_{\mathrm{q} 2}, \ldots \mathrm{w}_{\mathrm{q}}\right)$ berdasarkan istilah-istilah pada query dan sebuah vektor D $\left(\mathrm{d}_{\mathrm{i} 1}, \mathrm{~d}_{\mathrm{i} 2}, \ldots \mathrm{d}_{\mathrm{it}}\right)$ berukuran $\mathrm{t}$ untuk setiap dokumen. Pada umumnya cosine similarity $(C S)$ dihitung dengan rumus cosine measure (Grossman, 1998).

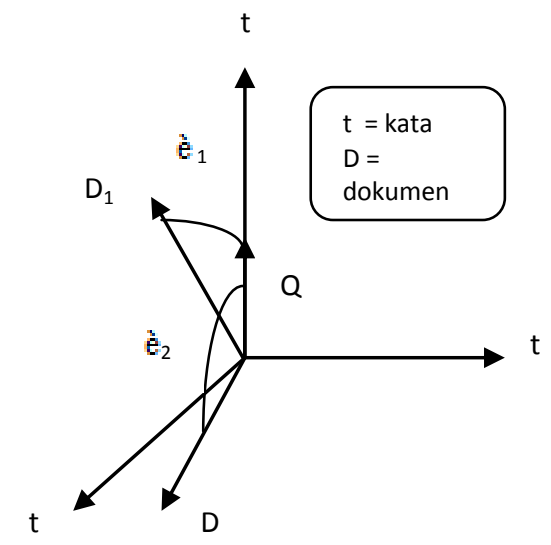

Gambar 1. Vektor Skalar

$$
\operatorname{cS}\left(b_{1}, b_{2}\right)=\frac{\sum_{t=1}^{n} w_{t, b_{1}} w_{t, b_{2}}}{\sqrt{\sum_{t=1}^{n} W_{t}^{n} b_{1} \sum_{j=1}^{n} w_{t, b_{2}}^{n}}}
$$

Keterangan:

$\mathrm{T}=$ term dalam kalimat

$\mathrm{w}_{\mathrm{t}, \mathrm{b} 1}=$ bobot term $\mathrm{t}$ dalam blok $\mathrm{b}_{1}$

$\mathrm{w}_{\mathrm{t}, \mathrm{b} 2}=$ bobot term $\mathrm{t}$ dalam blok $\mathrm{b}_{2}$

Model Dot product:

$$
C S(Q, D i)=(D i)(Q)
$$

Model Dice:

$$
S\langle(Q, D i)=2(D i)(Q) /(D i 2)(Q 2)
$$

Model Jaccard:

$$
C S(Q, D i)=(D i Q) /((D i) 2+Q 2-\|D i\| Q \mid]
$$

Model Cosine similarity Larson dan Herast:

$$
\operatorname{Cos} \operatorname{Sim}(d j, q)=\frac{\overrightarrow{d j} \cdot \vec{q}}{|\overrightarrow{d j}| \cdot|\vec{q}|}=\frac{\sum_{i=1}^{t}\left(W_{i j} \cdot W_{i q}\right)}{\sqrt{\sum_{i=1}^{t} W i j^{2} \cdot W i q^{2}}}(6)
$$

\subsection{Pembobotan TF-IDF}

Pembobotan dapat diperoleh berdasarkan jumlah kemunculan suatu term dalam sebuah dokumen term frequency (tf) dan jumlah kemunculan term dalam koleksi dokumen inverse document frequency (idf). Bobot suatu istilah semakin besar jika istilah tersebut sering muncul dalam suatu dokumen dan semakin kecil jika istilah tersebut muncul dalam banyak dokumen (Grossman, 1998). Nilai idf sebuah term (kata) dapat dihitung menggunakan persamaan sebagai berikut:

$$
I D F=\log \left(\frac{D}{d f i}\right)
$$

D adalah jumlah dokumen yang berisi term $(t)$ dan $d f i$ adalah jumlah kemunculan (frekuensi) term terhadap D. Adapun algoritma yang digunakan untuk menghitung bobot (W) masing-masing dokumen terhadap kata kunci (query), yaitu:

$$
\mathrm{W}_{\mathrm{d}, \mathrm{t}}=\mathrm{tf}_{\mathrm{d}, \mathrm{t}} * \mathrm{IDF}_{\mathrm{t}}
$$

Keterangan :

$\mathrm{d}=$ dokumen ke- $\mathrm{d}$

$\mathrm{t}=$ term $\mathrm{ke}-\mathrm{t}$ dari kata kunci

tf = term frekuensi/frekuensi kata

$\mathrm{W}=$ bobot dokumen ke- $\mathrm{d}$ terhadap term ke-t

Setelah bobot (W) masing-masing dokumen diketahui, maka dilakukan proses pengurutan (sorting) dimana semakin besar nilai $\mathrm{W}$, semakin besar tingkat kesamaan (similarity) dokumen tersebut terhadap kata yang dicari, demikian pula sebaliknya. 


\subsection{Text Preprocessing}

Text preprocessing adalah tahapan untuk mempersiapkan teks menjadi data yang akan diolah di tahapan berikutnya. Inputan awal pada proses ini adalah berupa dokumen. Text preprocessing pada penelitian ini terdiri dari beberapa tahapan, yaitu: proses pemecahan kalimat, proses case folding, proses tokenizing kata, proses filtering, dan proses stemming

\subsubsection{Pemecahan Kalimat}

Memecah dokumen menjadi kalimatkalimat merupakan langkah awal tahapan text preprocessing. Pemecahan kalimat yaitu proses memecah string teks dokumen yang panjang menjadi kumpulan kalimat-kalimat. Dalam memecah dokumen menjadi kalimat-kalimat menggunakan fungsi split(), dengan tanda titik ".", tanda tanya "?" dan tanda tanya "!" sebagai delimiter untuk memotong string dokumen.

\subsubsection{Case Folding}

Case folding adalah tahapan proses mengubah semua huruf dalam teks dokumen menjadi huruf kecil, serta menghilangkan karakter selain a-z.

\subsubsection{Tokenizing}

Tokenizing adalah proses pemotongan string input berdasarkan tiap kata yang menyusunnya. Pemecahan kalimat menjadi kata-kata tunggal dilakukan dengan men-scan kalimat dengan pemisah (delimiter) white space (spasi, tab, dan newline).

\subsubsection{Filtering}

Filtering merupakan proses penghilangan stopword. Stopword adalah katakata yang sering kali muncul dalam dokumen namun artinya tidak deskriptif dan tidak memiliki keterkaitan dengan tema tertentu. Didalam bahasa Indonesia stopword dapat disebut sebagai kata tidak penting, misalnya "di", "oleh", "pada", "sebuah", "karena" dan lain sebagianya.
Tabel 1. Aturan Pembentukan Partikel Infleksional

\begin{tabular}{|r|l|l|l|}
\hline Sufiks & Pengganti & $\begin{array}{l}\text { Kondisi } \\
\text { Tambahan }\end{array}$ & Contoh \\
\hline Kah & NULL & NULL & bukukah $\rightarrow$ buku \\
\hline lah & NULL & NULL & terimalah $\rightarrow$ terima \\
\hline tah & NULL & NULL & apatah $\rightarrow$ apa \\
\hline pun & NULL & NULL & bukupun $\rightarrow$ buku \\
\hline
\end{tabular}

Tabel 2. Aturan Pembentukan Kata Ganti Milik Infleksional

\begin{tabular}{|l|r|r|l|}
\hline Sufiks & Pengganti & $\begin{array}{l}\text { Kondisi } \\
\text { Tambahan }\end{array}$ & Contoh \\
\hline $\mathrm{ku}$ & NULL & NULL & bukuku $\rightarrow$ buku \\
\hline $\mathrm{mu}$ & NULL & NULL & bukumu $\rightarrow$ buku \\
\hline nya & NULL & NULL & bukunya $\rightarrow$ buku \\
\hline
\end{tabular}

\subsubsection{Stemming}

Stemming merupakan proses mencari akar (root) kata dari tiap token kata yaitu dengan pengembalian suatu kata berimbuhan ke bentuk dasarnya (stem) (Tala, 2003). Pada penelitian ini menggunakan porter stemming untuk bahasa indonesia (Tala, 2003). Terdapat lima aturan pada proses stemming untuk bahasa Indonesia menggunakan porter stemmer, yaitu ada lima aturan tahap dalam proses stemming pada bahasa Indonesia, yaitu :

1) Penanganan terhadap partikel inflek sional, yaitu: lah, tah, kah. Contoh: duduklah, makanlah.

2) Penanganan terhadap kata ganti infleksional, yaitu: $\mathrm{ku}, \mathrm{mu}$, dan nya. Contoh: sepedaku, bukunya.

3) Penanganan terhadap prefiks derivasional pertama, yaitu : meng dan semua variasinya, peng dan semua variasinya, di, ter, dan ke. contoh : membakar, pengukur, kekasih.

4) Penanganan terhadap prefix derivasional kedua, yaitu : ber dan semua variasinya serta per dan semua variasinya. Contoh: berlari, belajar, perkata.

5) Penanganan terhadap Sufiks derivasional, yaitu kan, am dan i. Contoh: ambilkan, janjian dan dapati.

Karena struktur morfologi bahasa Indonesia yang rumit maka kelima tahap aturan tidak cukup untuk menangani proCreated with 
ses stemming bahasa Indonesia. Kesulitan membedakan kata yang mengandung imbuhan baik prefiks maupun sufiks dari kata dasar yang salah satu suku katanya merupakan bagian imbuhan, terutama dengan kata dasar yang mempunyai suku kata lebih besar dari dua.

Tabel 3. Aturan Pembentukan Prefiks Derivasional Pertama

\begin{tabular}{|l|l|l|l|}
\hline Prefiks & Pengganti & $\begin{array}{l}\text { Kondisi } \\
\text { Tambahan }\end{array}$ & Contoh \\
\hline meng & NULL & NULL & mengukur $\rightarrow$ ukur \\
\hline meny & $\mathrm{s}$ & $\mathrm{V} \ldots{ }^{*}$ & menyapu $\rightarrow$ sapu \\
\hline men & NULL & NULL & menduga $\rightarrow$ duga \\
\hline men & $\mathrm{t}$ & $\mathrm{V} \ldots$ & menuduh $\rightarrow$ tuduh \\
\hline mem & $\mathrm{p}$ & $\mathrm{V} \ldots$ & memilah $\rightarrow$ pilah \\
\hline mem & NULL & NULL & membaca $\rightarrow$ baca \\
\hline me & NULL & NULL & merusak $\rightarrow$ rusak \\
\hline peng & NULL & NULL & pengukur $\rightarrow$ ukur \\
\hline peny & $\mathrm{s}$ & V $\ldots$ & penyelam $\rightarrow$ selam \\
\hline pen & NULL & NULL & pendaki $\rightarrow$ daki \\
\hline pen & t & V $\ldots$ & penari $\rightarrow$ tari \\
\hline pem & p & V $\ldots$ & pemilah $\rightarrow$ pilah \\
\hline pem & NULL & NULL & pembaca $\rightarrow$ baca \\
\hline di & NULL & NULL & diukur $\rightarrow$ ukur \\
\hline ter & NULL & NULL & tersipu $\rightarrow$ sipu \\
\hline ke & NULL & NULL & kekasih $\rightarrow$ kasih \\
\hline
\end{tabular}

Tabel 4. Aturan Pembentukan Prefiks Derivasional Kedua

\begin{tabular}{|c|l|c|l|}
\hline Prefiks & Pengganti & $\begin{array}{c}\text { Kondisi } \\
\text { Tambahan }\end{array}$ & Contoh \\
\hline Ber & NULL & NULL & berlari $\rightarrow$ lari \\
\hline Bel & NULL & Ajar & belajar $\rightarrow$ ajar \\
\hline Be & NULL & Kerja & bekerja $\rightarrow$ kerja \\
\hline Per & NULL & NULL & perjelas $\rightarrow$ jelas \\
\hline Pel & NULL & Ajar & pelajar $\rightarrow$ ajar \\
\hline Pe & NULL & NULL & pekerja $\rightarrow$ kerja \\
\hline
\end{tabular}

Tabel 5. Aturan Pembentukan Sufiks Derivasional

\begin{tabular}{|l|l|l|l|}
\hline Sufiks & Pengganti & $\begin{array}{l}\text { Kondisi } \\
\text { Tambahan }\end{array}$ & Contoh \\
\hline kan & NULL & $\begin{array}{l}\text { prefiks } \\
\varnothing\{\text { ke, peng }\}\end{array}$ & $\begin{array}{l}\text { tarikkan } \rightarrow \text { tarik } \\
\text { (meng)ambilkan } \rightarrow \\
\text { ambil }\end{array}$ \\
\hline An & NULL & $\begin{array}{l}\text { prefiks } \varnothing\{\text { di, } \\
\text { meng, ter }\}\end{array}$ & $\begin{array}{l}\text { makanan } \rightarrow \text { makan } \\
\text { (per)janjian } \rightarrow \text { janji }\end{array}$ \\
\hline I & NULL & $\begin{array}{l}\text { prefiks } \\
\varnothing\{\text { ber, ke, } \\
\text { peng }\}\end{array}$ & $\begin{array}{l}\text { tandai } \rightarrow \text { tanda } \\
\text { (men)dapati } \\
\text { dapat }\end{array}$ \\
\hline
\end{tabular}

Contoh :

- sekolah $\rightarrow$ sekolah (kata dasar, tidak dilakukan stemming)

- duduklah $\rightarrow$ duduk (dilakukan proses stemming)

Berdasarkan urutan tahapan pada penanganan kata berimbuhan, maka terdapat beberapa kemungkinan dalam kesulitan membedakan suatu suku kata merupakan imbuhan atau bagian kata dasar :

1) Kata dasar mempunyai suku kata terakhir (partikel infleksional) serta kata tersebut tidak mendapat imbuhan apapun. Contoh: istilah.

2) Kata dasar mempunyai suku kata terakhir (partikel infleksional) dan mempunyai prefiks. Contoh: bersalah.

3) Kata dasar mempunyai suku kata terakhir (kata ganti infleksional) serta kata dasar tersebut tidak mendapatkan imbuhan apapun. Contoh : bangku.

4) Kata dasar mempunyai suku kata terakhir (kata ganti infleksional) dan mengandung prefiks. Contoh: bertanya.

5) Kata dasar mempunyai suku kata pertama (prefiks derivasional pertama) serta kata dasar tersebut tidak mendapatkan imbuhan apapun. Contoh: diagram, kenang.

6) Kata dasar mempunyai suku kata pertama (prefiks derivasional pertama) dan mempunyai sufiks derivasional. Contoh: disiplinkan, pentungan.

7) Kata dasar mempunyai suku kata pertama (prefiks derivasional kedua) serta kata dasar tersebut tidak mendapatkan imbuhan apapun. Contoh : pelangi, perban.

8) Kata dasar mempunyai suku kata pertama (prefiks derivasional) dan mempunyai sufiks derivasional. Contoh: belakangan, pejamkan

9) Kata dasar mempunyai suku kata terakhir (sufiks derivasional). Contoh: koleksi, dominan.

Berdasarkan dari permasalahan tersebut, maka dibuat kamus-kamus kecil untuk melengkapi proses stemming ini. Terdapat 9 kamus kecil, yaitu :

1) Kamus partikel. Seperti: masalah 
2) Kamus partikel berprefiks. Seperti: menikah

3) Kamus milik. Seperti: bangku.

4) Kamus milik berprefiks. Seperti: bersuku.

5) Kamus prefiks 1. Seperti: median.

6) Kamus prefiks 1 bersufiks. Seperti: terapan.

7) Kamus prefiks 2. Seperti : percaya.

8) Kamus prefiks 2 bersufiks. Seperti: perasaan.

9) Kamus sufiks. Seperti: pantai.

Kondisi ukuran adalah jumlah minimum suku kata dalam sebuah kata. Karena dalam bahasa Indonesia, kata dasar setidaknya mempunyai 2 suku kata. Maka kondisi ukuran dalam proses stemming bahasa Indonesia adalah dua. Suku kata didefinisikan memiliki satu vokal.

\subsection{Tipe Evaluasi}

Metode untuk mengevaluasi hasil ringkasan merupakan topik yang cukup sulit, baik evaluasi terhadap ringkasan yang dihasilkan dari mesin peringkas otomatis ataupun ringkasan yang manual dibuat oleh abstractor yang profesional, dikarenakan tidak terdapat definisi ringkasan ideal. Terdapat dua klasifikasi metode evaluasi (Sparck dan Galliers, 1996), yaitu :

a. Ekstrinsik

Kualitas ringkasan diukur berdasarkan bagaimana ini membantu penyelesaian tugas user.

b. Intrinsik

Hanya diukur dari kualitas hasil (output) ringkasan yang dihasilkan.

Evaluasi sistem peringkas yang ada saat ini adalah intrinsik. Pengevaluasi menciptakan sekumpulan ringkasan yang manual, masing-masing satu untuk menguji teks. Kemudian membandingkan hasil ringkasan sistem dengan ringkasan ideal. Yang diukur adalah overlap dari isi, seringkali disebut dengan recall dan precision kalimat atau frase, tapi kadangkadang dengan overlap kata tunggal.

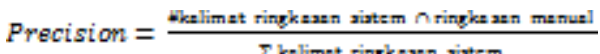

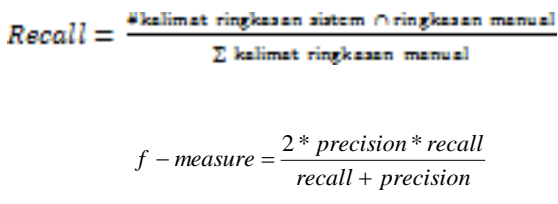

Precision (persamaan 9) dan recall (persamaan 10) digunakan untuk mengukur kualitas sebuah ringkasan. Pengukuran precision dan recall ini sangat dipengaruhi oleh panjang ringkasan manual dan juga panjang ringkasan yang dievaluasi. Akurasi menurun sejalan dengan bertambahnya panjang ringkasan. Sulit untuk mengambil kesimpulan terhadap performance sistem dari nilai precision dan recall. Untuk standarisasi proses evaluasi belum dieksplorasi. Masalah utama dari evaluasi ini adalah sangat nyata, yaitu tidak ada satupun ringkasan yang benar (Edmudson, 1969). Kombinasi antara nilai recall dan precision menghasilkan $f$ measure (persamaan 11).

\section{METODOLOGI}

Pada penelitian ini, peringkasan teks otomatis berita yang dibuat merupakan sistem peringkasan dengan inputan berupa single dokumen dan secara otomatis menghasilkan ringkasan (summary). Proses peringkasan teks otomatis pada penelitian ini terdiri dari: proses text preprosessing, pembobotan tf-idf kata, pembobotan relevance query, pembobotan similarity kalimat, pembobotan MMR dan ekstraksi ringkasan. Gambar 2 menunjukkan bagan proses peringkasan secara umum. Berikut ini alur proses peringkasan sistem:

1) User memasukkan teks dokumen yang akan diringkas dan memasukkan kalimat query. Proses awal peringkasan user memasukkan teks dokumen dan query sesuai Tabel 6.

2) Sistem melakukan penyiapan teks (text preprosessing) dokumen yang terdiri dari tahap pemecahan kalimat, case folding, tokenizing kata, filtering dan stemming. 


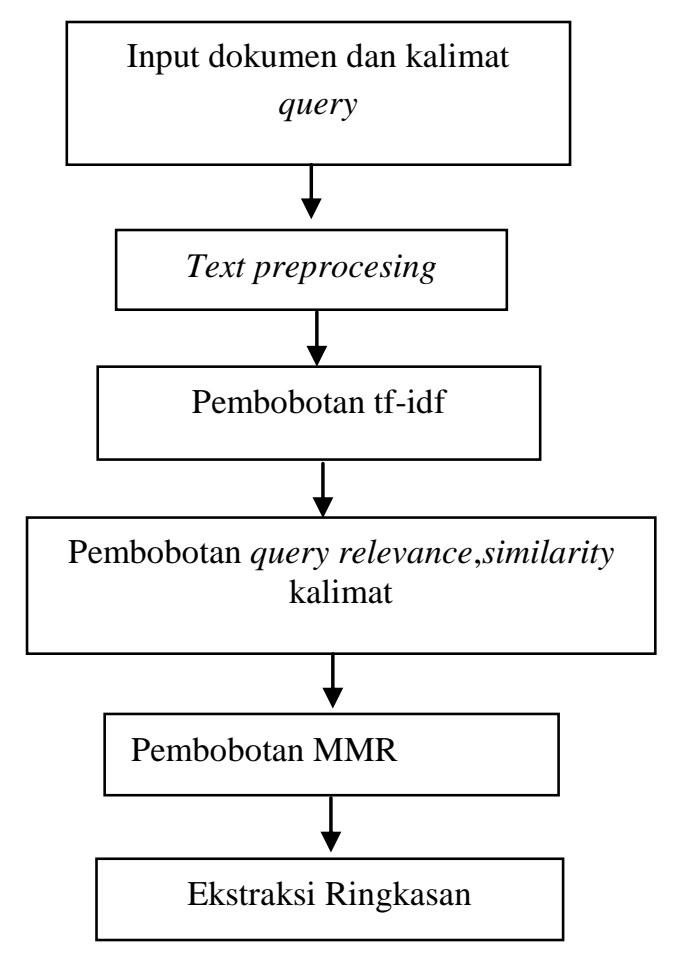

Gambar 2. Proses Peringkasan

Tabel 6. Teks Asal dan Query

Isi: Tempo interaktif, london: hubungan mesra antara chelsea dengan didier drogba tampaknya akan segera berakhir. Striker pantai gading itu kemungkinan akan mendapat denda 100,000 poundstering (rp 1,5 miliar) akibat mengkritik klub yang menurutnya tidak mendukung performanya di stamford bridge musim ini. Nilai denda itu setara gaji sepekan yang diterima drogba. Dia juga mengaku tidak berminat untuk kembali bermain setelah dibekap cedera lutut dan mengkritik gaya pemilihan pemain yang ditunjukkan luiz felipe scolari. Komentarnya jelas membuat big phil dan ceo the blues peter kenyon marah. Atas aksinya ini klub telah memanggil drogba yang mungkin memilih mengakhiri kariernya bersama chelsea yang dimulainya sejak 2004 setelah hengkang dari marseille.

Query: chelsea denda drogba

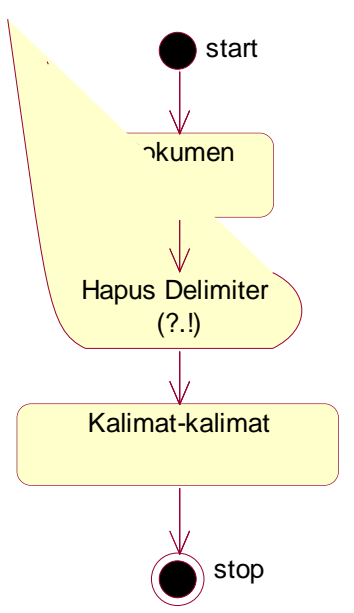

Gambar 3. Activity Diagram Pemecahan Kalimat
Tabel 7. Pemecahan Kalimat

\begin{tabular}{|c|l|}
\hline No & \multicolumn{1}{|c|}{ Kalimat } \\
\hline 1 & $\begin{array}{l}\text { Tempo interaktif, London: hubungan mesra antar } \\
\text { Chelsea dengan Didier Drogba tampaknya akan seger } \\
\text { berakhir }\end{array}$ \\
\hline 2 & $\begin{array}{l}\text { Striker pantai gading itu kemungkinan akan mendapa } \\
\text { denda 100,000 poundstering (rp 1,5 miliar) akiba } \\
\text { mengkritik klub yang menurutnya tidak mendukung } \\
\text { performanya di Stamford Bridge musim ini }\end{array}$ \\
\hline 3 & Nilai denda itu setara gaji sepekan yang diterima Drogba \\
\hline 4 & $\begin{array}{l}\text { Dia juga mengaku tidak berminat untuk kembal } \\
\text { bermain setelah dibekap cedera lutut dan mengkritil } \\
\text { gaya pemilihan pemain yang ditunjukkan Luiz Felip } \\
\text { Scolari }\end{array}$ \\
\hline 5 & $\begin{array}{l}\text { Komentarnya jelas membuat big phil dan ceo the blue } \\
\text { Peter Kenyon marah }\end{array}$ \\
\hline 6 & $\begin{array}{l}\text { Atas aksinya ini klub telah memanggil Drogba yang } \\
\text { mungkin memilih mengakhiri kariernya bersama } \\
\text { Chelsea yang dimulainya sejak 2004 setelah hengkang } \\
\text { dari Marseille }\end{array}$ \\
\hline
\end{tabular}

\subsection{Pemecahan Kalimat}

Tahap pemecahan kalimat adalah memecah string dokumen menjadi kumpulan kalimat dengan menghilangkan tanda tanda akhir kalimat (delimiter). Tanda baca akhir kalimat seperti tanda titik “.”, tanda tanya “?”, dan tanda seru "!". Gambar 3 adalah activity diagram pemecahan kalimat. Tabel 7 merupakan hasil proses pemecahan dokumen menjadi kumpulan kalimat dengan inputan artikel (tabel 6).

\subsection{Case Folding}

Tahap ini, kumpulan kalimat hasil pemecahan diubah menjadi huruf kecil (lower case), menghilangkan angka, tanda baca maupun simbo dan hanya menerima karakter UTF8 dengan kode 0061- 007A). Alur activity diagram case folding pada Gambar 4.

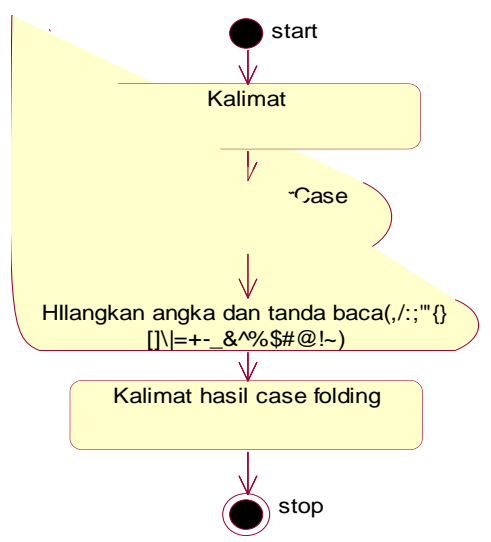

Gambar 4. Activity Diagram Case Folding

Created with 
Tabel 8. Case Folding

\begin{tabular}{|c|l|}
\hline No & \multicolumn{1}{|c|}{ Kalimat } \\
\hline 1 & $\begin{array}{l}\text { tempo interaktif london hubungan mesra antara } \\
\text { chelsea dengan didier drogba tampaknya akan } \\
\text { segera berakhir }\end{array}$ \\
\hline 2 & $\begin{array}{l}\text { striker pantai gading itu kemungkinan akan } \\
\text { mendapat denda poundstering rp miliar akibat } \\
\text { mengkritik klub yang menurutnya tidak } \\
\text { mendukung performanya di stamford bridge } \\
\text { musim ini }\end{array}$ \\
\hline 3 & $\begin{array}{l}\text { nilai denda itu setara gaji sepekan yang diterima } \\
\text { drogba }\end{array}$ \\
\hline 4 & $\begin{array}{l}\text { dia juga mengaku tidak berminat untuk kembali } \\
\text { bermain setelah dibekap cedera lutut dan } \\
\text { mengkritik gaya pemilihan pemain yang } \\
\text { ditunjukkan luiz felipe scolari }\end{array}$ \\
\hline 5 & $\begin{array}{l}\text { komentarnya jelas membuat big phil dan ceo the } \\
\text { blues peter kenyon marah }\end{array}$ \\
\hline 6 & $\begin{array}{l}\text { atas aksinya ini klub telah memanggil drogba } \\
\text { yang mungkin memilih mengakhiri kariernya } \\
\text { bersama chelsea yang dimulainya sejak setelah } \\
\text { hengkang dari marseille }\end{array}$ \\
\hline
\end{tabular}

Tabel 8 merupakan hasil case folding dari data di tabel 7. Huruf awal dari setiap kalimat diubah menjadi huruf kecil. Pada kalimat pertama dan kedua string angka, tanda baca titik dua ":", tanda baca koma ",", tanda kurung buka dan tutup "()" dihilangkan.

\subsection{Tokenizing}

Kumpulan kalimat hasil dari case folding kemudian dilakukan proses tokenizing kata yaitu menghilangkan karakter pemisah (delimiter) yang menyusunnya berupa karakter spasi (UTF8 kode 0020). Alur activity diagram tokenizing dapat ditunjukkan pada Gambar 5. Berdasarkan tabel 9, proses tokenizing menghasilkan token kata sejumlah 56 kata.

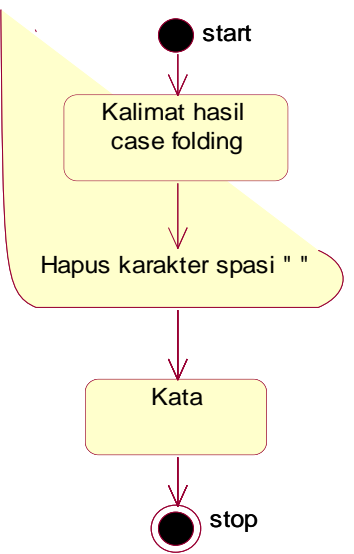

Gambar 5. Activity Diagram Tokenizing
Tabel 9. Hasil Tokenizing

\begin{tabular}{|c|c|c|}
\hline Kata & Kata & Kata \\
\hline aksinya & Drogba & marseille \\
\hline bermain & Felipe & memanggil \\
\hline berminat & Gading & memilih \\
\hline big & Gaji & mendukung \\
\hline blues & Gaya & mengakhiri \\
\hline bridge & hengkang & mengkritik \\
\hline cedera & interaktif & mesra \\
\hline ceo & kariernya & miliar \\
\hline chelsea & kenyon & musim \\
\hline denda & Klub & nilai \\
\hline dibekap & komentarnya & pantai \\
\hline didier & London & pemain \\
\hline dimulainya & Luiz & pemilihan \\
\hline diterima & Lutut & performanya \\
\hline ditunjukkan & Marah & peter \\
\hline phil & Scolari & stamford \\
\hline poundstering & sepekan & striker \\
\hline $\mathrm{rp}$ & Setara & tempo \\
\hline hubungan & Antara & dengan \\
\hline akan & Segera & itu \\
\hline kemungkinan & Akibat & yang \\
\hline menurutnya & Tidak & $\mathrm{di}$ \\
\hline ini & Dia & juga \\
\hline setelah & Dan & jelas \\
\hline the & Atas & telah \\
\hline mungkin & bersama & sejak \\
\hline
\end{tabular}

\subsection{Filtering}

Pada tahap ini, dilakukan pembuangan kata-kata yang dianggap kurang penting. Stopword adalah kata-kata yang kurang deskriptif yang dapat dibuang dalam pendekatan bag-of-words. Pembuangan stopword dilakukan dengan mengecek kamus stopword. Jika terdapat kata yang sama dengan kamus maka akan dihapus. Alur activity filtering pada Gambar 5. Kata hasil token dicek terlebih dahulu untuk dicocokkan dengan kamus stopword. Jika dalam pencocokan terdapat kata yang sama dalam kamus maka kata tersebut dihilangkan. Berdasarkan Tabel 10 kata-kata yang termasuk dalam stopword adalah : antara, akan, dengan, hubungan, segera, itu, kemungkinan, akibat, yang, tidak, di, menurutnya, ini, dia, juga, setelah, dan, jelas, the, atas, telah, mungkin, bersama dan sejak.

\section{Created with}




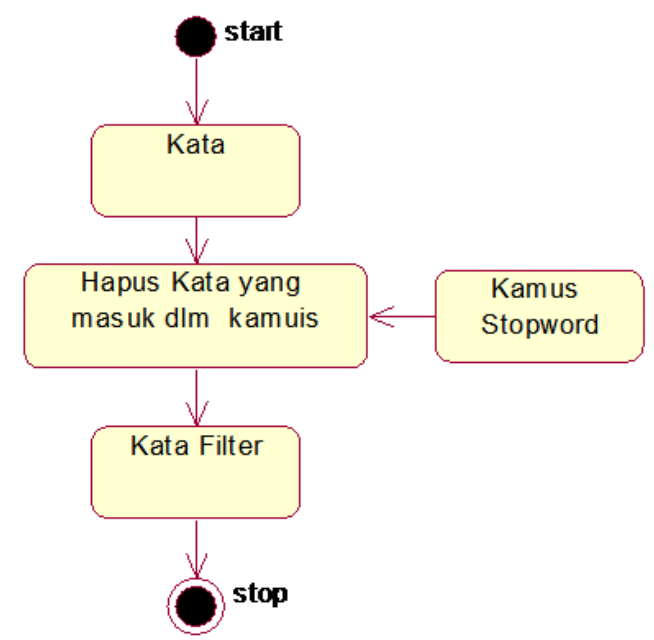

Gambar 6. Activity Diagram Filtering

Tabel 10. Hasil Filtering

\begin{tabular}{|c|c|c|}
\hline Kata & Kata & Kata \\
\hline aksinya & drogba & marseille \\
\hline bermain & felipe & memanggil \\
\hline berminat & gading & memilih \\
\hline big & gaji & mendukung \\
\hline blues & gaya & mengakhiri \\
\hline bridge & hengkang & mengkritik \\
\hline cedera & interaktif & mesra \\
\hline ceo & kariernya & miliar \\
\hline chelsea & kenyon & musim \\
\hline denda & klub & nilai \\
\hline dibekap & komentarnya & pantai \\
\hline didier & london & pemain \\
\hline dimulainya & luiz & pemilihan \\
\hline diterima & Lutut & performanya \\
\hline ditunjukkan & marah & peter \\
\hline phil & scolari & stamford \\
\hline poundstering & sepekan & striker \\
\hline rp & setara & tempo \\
\hline
\end{tabular}

\subsection{Stemming}

Hasil filtering kemudian di-stemming untuk mendapatkan kata dasar (root). Proses stemming menggunakan bantuan kamus-kamus kecil dengan untuk membedakan suatu kata yang mengandung imbuhan baik prefiks maupun sufiks yang salah satu suku katanya merupakan bagian dari imbuhan, terutama dengan kata dasar yang mempunyai suku kata lebih besar dari dua. Alur activity diagram stemming sesuai Gambar 7.

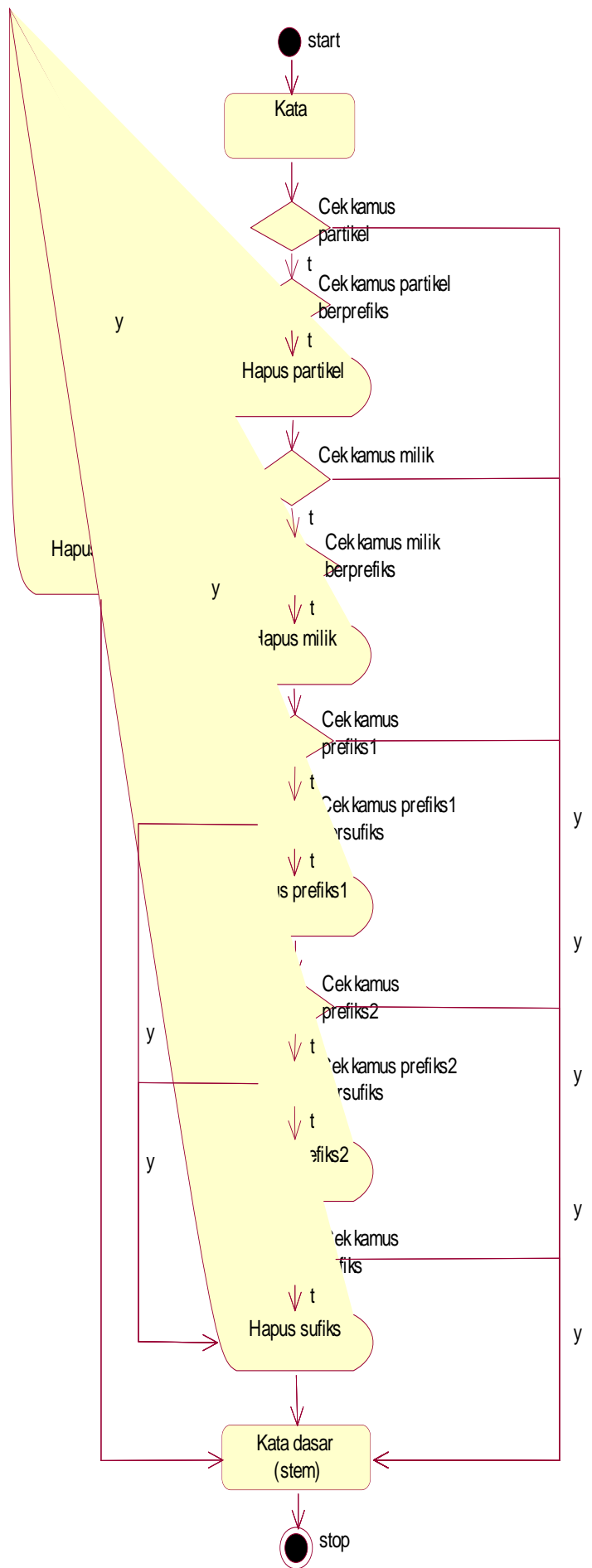

Gambar 7. Activity Diagram Stemming

Dari proses stemming terdapat katakata yang mengalami penghilangan imbuhan, baik prefiks maupun sufiks. Kata-kata yang telah dihilangkan prefiks maupun sufiks dapat dilihat pada Tabel 11. Di antara kata-kata tersebut adalah : aksi, main, panggil, pilih, bekap, Created with 
performa, dukung, akhir, minat, kritik, tunjuk dan terima.

Tabel 11. Hasil Stemming

\begin{tabular}{|c|c|c|}
\hline Kata & Kata & Kata \\
\hline aksi & drogba & marseille \\
\hline main & felipe & panggil \\
\hline minat & gading & pilih \\
\hline big & gaji & dukung \\
\hline blues & gaya & akhir \\
\hline bridge & hengkang & kritik \\
\hline cedera & interaktif & mesra \\
\hline ceo & karier & miliar \\
\hline chelsea & kenyon & musim \\
\hline denda & klub & nilai \\
\hline bekap & komentar & pantai \\
\hline didier & london & main \\
\hline mulai & luiz & pilih \\
\hline terima & lutut & performa \\
\hline tunjuk & marah & peter \\
\hline phil & scolari & stamford \\
\hline poundstering & sepekan & striker \\
\hline rp & setara & tempo \\
\hline
\end{tabular}

Hasil proses text preprosessing dilakukan pembobotan tf-idf. Pembobotan secara otomatis biasanya berdasarkan jumlah kemunculan suatu kata dalam sebuah dokumen (term frequency) dan jumlah kemunculannya dalam koleksi dokumen (inverse document frequency). Bobot kata semakin besar jika sering muncul dalam suatu dokumen dan semakin kecil jika muncul dalam banyak dokumen. Pembobotan tf-idf dilakukan untuk pembobotan tahap selanjutnya, yaitu untuk menghitung bobot query relevance dan bobot similarity kalimat. Alur activity pada bobot tf-idf untuk relevance query adalah sama seperti activity pada bobot tf-idf untuk similarity kalimat. Alur activity bobot tf-idf pada Gambar 8.

Perhitungan bobot query relevance merupakan bobot hasil perbandingan kemiripan (similaritas) antara query yang dimasukkan oleh user terhadap keseluruhan kalimat. Sedangkan bobot similarity kalimat, merupakan bobot hasil perbandingan kemiripan antar kalimat. Alur activity diagram bobot query relevance pada Gambar 9 dan bobot similarity pada Gambar 10.

Tabel 12 adalah hasil perhitungan bobot query relevance yaitu menghitung bobot kemiripan antara query dengan kalimat dalam dokumen sesuai persamaan (6). Perhitungan bobot query relevance ini menggunakan metode cosine similarity dengan menghitung cosinus sudut dari dua vector, yaitu $\mathrm{W}$, bobot dari tiap kalimat dan W (bobot) query. Tabel 13 adalah hasil pembobotan similarity kalimat menggunakan persamaan (6),

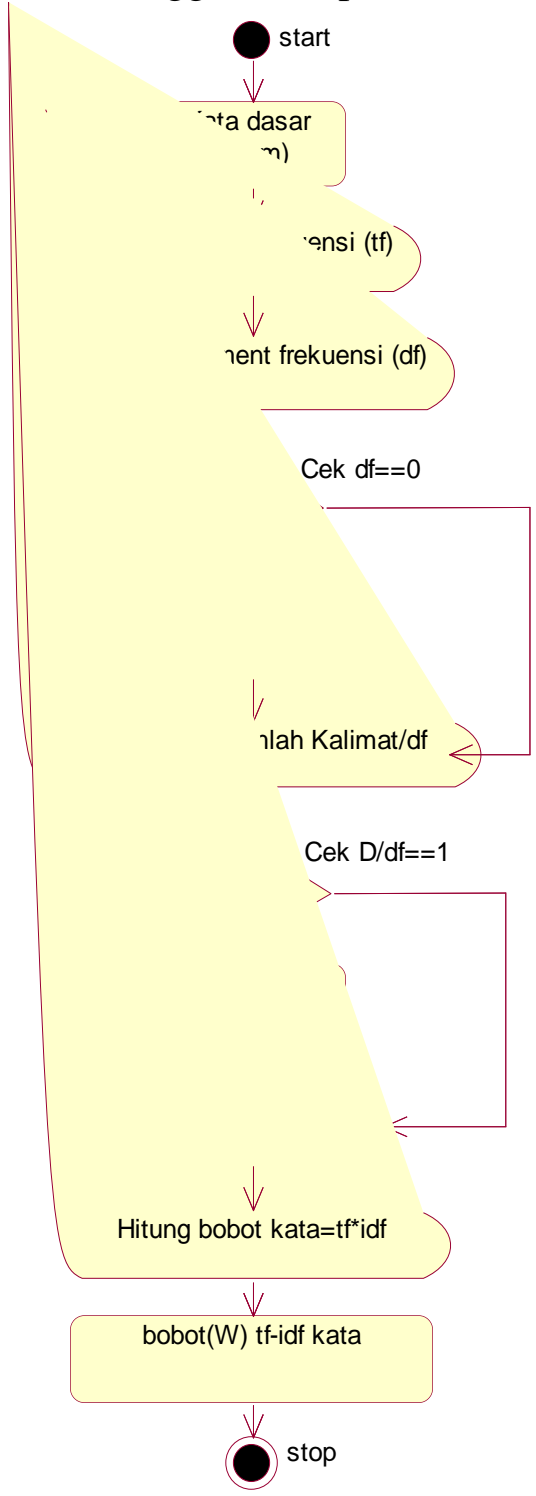

Gambar 8. Activity Diagram bobot tf-idf 
Tabel 12. Bobot query relevance

\begin{tabular}{|l|l|l|l|l|l|}
\hline S1 & S2 & S3 & S4 & S5 & S6 \\
\hline 0.202 & 0.109 & 0.235 & 0 & 0 & 0.205 \\
\hline
\end{tabular}

Tabel 13. Bobot similarity kalimat

\begin{tabular}{|l|l|l|l|l|l|l|}
\hline & S1 & S2 & S3 & S4 & S5 & S6 \\
\hline S1 & $\mathbf{1}$ & 0 & 0.023 & 0 & 0 & 0.071 \\
\hline S2 & 0 & $\mathbf{1}$ & 0.044 & 0.028 & 0 & 0.038 \\
\hline S3 & 0.023 & 0.044 & $\mathbf{1}$ & 0 & 0 & 0.024 \\
\hline S4 & 0 & 0.028 & 0 & $\mathbf{1}$ & 0 & 0.038 \\
\hline S5 & 0 & 0 & 0 & 0 & $\mathbf{1}$ & 0 \\
\hline S6 & 0.071 & 0.038 & 0.024 & 0.038 & 0 & $\mathbf{1}$ \\
\hline
\end{tabular}

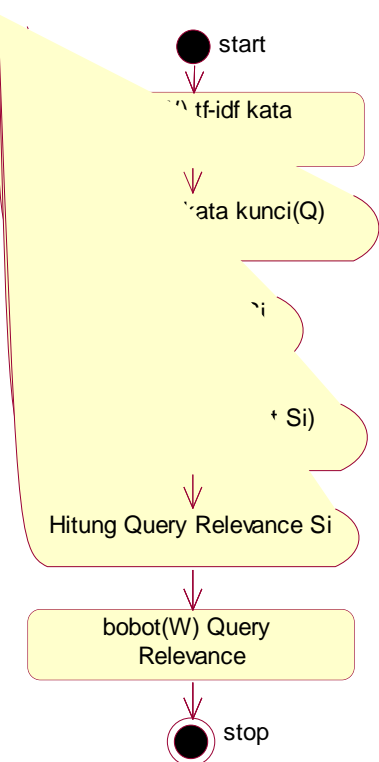

Gambar 9. Activity Diagram Bobot Query Relevance

Pembobotan MMR kalimat menggunakan algoritma maximum marginal relevance, kalimat dirangking sebagai tanggapan terhadap query yang diberikan oleh user. Perhitungan MMR dilakukan dengan perhitungan iterasi antara kombinasi dua matrik cosine similarity yaitu query relevance dan similarity kalimat. Pengguna yang menginginkan ruang sampel informasi disekitar query, maka harus menetapkan $\lambda$ pada nilai yang lebih rendah. Sedangkan bagi pengguna yang ingin fokus untuk memperkuat dokumen-dokumen lebih relevan, maka harus menetapkan $\lambda$ pada nilai yang lebih dekat dengan $\lambda$. Kalimat dengan nilai $M M R$ tertinggi dari setiap perhitungan iterasi akan diambil, kemudian dipilih sebagai ringkasan. Iterasi berhenti pada saat hasil $M M R$ maksimum sama dengan 0. Alur activity bobot $M M R$ pada Gambar 11 .

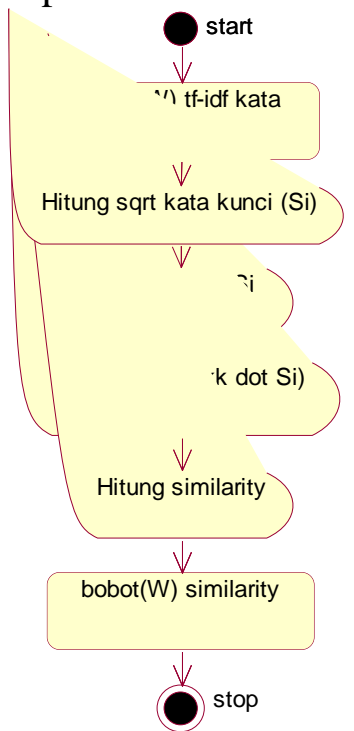

Gambar 10. Activity Diagram Bobot Similarity

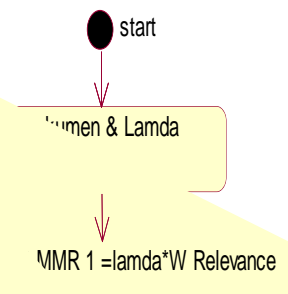

'R1

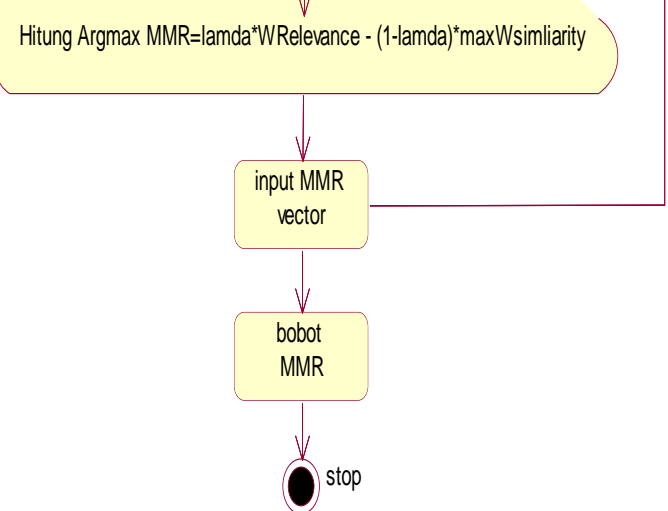

Gambar 11. Activity Diagram Bobot MMR 
Tabel 14. Hasil Iterasi MMR

\begin{tabular}{|l|l|l|l|l|l|l|}
\hline $\begin{array}{l}\text { Iterasi } \\
\text { ke }\end{array}$ & S1 & S2 & S3 & S4 & $\begin{array}{l}\text { S } \\
5\end{array}$ & S6 \\
\hline 1 & 0.141 & 0.076 & $\mathbf{0 . 1 6 5}$ & 0 & 0 & 0.144 \\
\hline 2 & 0.134 & 0.063 & - & 0 & 0 & $\mathbf{0 . 1 3 7}$ \\
\hline 3 & $\mathbf{0 . 1 2 0}$ & 0.065 & - & 0 & 0 & - \\
\hline 4 & - & $\mathbf{0 . 0 6 3}$ & - & 0 & 0 & - \\
\hline 5 & - & - & - & - & $\mathbf{0}$ & - \\
\hline
\end{tabular}

Tabel 15. Hasil bobot MMR maksimum iterasi MMR

\begin{tabular}{|l|l|l|}
\hline Iterasi ke & $\begin{array}{l}\text { Kalima } \\
\mathrm{t}\end{array}$ & Bobot ArgMax MMR \\
\hline MMRMAX(1) & $\mathrm{S} 3$ & 0.165 \\
\hline MMRMAX(2) & $\mathrm{S} 6$ & 0.137 \\
\hline MMRMAX(3) & $\mathrm{S} 1$ & 0.120 \\
\hline MMRMAX(4) & $\mathrm{S} 2$ & 0.063 \\
\hline
\end{tabular}

Tabel 16. Hasil Ekstraksi

\begin{tabular}{|l|l|}
\hline $\begin{array}{l}\text { Kalimat } \\
\text { ke }\end{array}$ & Kalimat \\
\hline S3 & $\begin{array}{l}\text { Nilai denda itu setara gaji sepekan yang } \\
\text { diterima Drogba }\end{array}$ \\
\hline S6 & $\begin{array}{l}\text { Atas aksinya ini klub telah memanggil } \\
\text { Drogba yang mungkin memilih mengakhiri } \\
\text { kariernya bersama Chelsea yang dimulainya } \\
\text { sejak 2004 setelah hengkang dari Marseille }\end{array}$ \\
\hline S1 & $\begin{array}{l}\text { Tempointeraktif, London: hubungan mesra } \\
\text { antara Chelsea dengan Didier Drogba } \\
\text { tampaknya akan segera berakhir }\end{array}$ \\
\hline S2 & $\begin{array}{l}\text { Striker pantai gading itu kemungkinan akan } \\
\text { mendapat denda 100,000 poundstering (rp } \\
\text { 1,5 miliar) akibat mengkritik klub yang } \\
\text { menurutnya tidak mendukung performanya } \\
\text { di Stamford Bridge musim ini }\end{array}$ \\
\hline
\end{tabular}

Tahap terakhir adalah ekstraksi ringkasan dari hasil bobot $M M R$ kalimat. Dari hasil perhitungan $\mathrm{mmr}$ diketahui kalimat yang menjadi ringkasan berdasarkan urutan bobot MMR kalimat tertinggi dapat dilihat pada tabel 16 .

\section{HASIL UJI COBA}

Data yang digunakan sebagai uji coba sejumlah 30 berita. Data uji coba diambil secara acak dari koran berita online Tempo Interaktif yang diunduh dari bulan Januari 2009 sampai Juni 2009. Uji coba dilakukan dengan menguji tiap teks berita. Pengujian dilakukan dengan memasukkan isi dari teks berita dan query. Query merupakan judul dari berita. Kalimat-kalimat yang terambil sebagai ringkasan merupakan kalimat yang merepresentasikan query, karena memiliki kesamaan kata-kata pada kalimat query, dan memiliki bobot $M M R$ maksimum antara nilai bobot maksimum 1 hingga bobot minimum 0. Semakin banyak kata-kata yang sama dengan query maka semakin besar peluang kalimat terambil sebagai ringkasan. Tabel 17 menunjukkan hasil keseluruhan uji coba yang dilakukan pada sistem peringkasan teks otomatis.

Kualitas ringkasan sistem diukur dengan membandingkan dengan ringkasan manual. Ringkasan manual diperoleh dari mayoritas kalimat yang dipilih oleh enam orang responden. Kualitas ringkasan dihitung dengan nilai recall, precision dan $f$ measure menggunakan persamaan (9), (10) dan (11).

Tabel 17. Hasil Ringkasan Sistem

\begin{tabular}{|c|c|c|}
\hline $\begin{array}{l}\text { Nomor } \\
\text { Berita }\end{array}$ & $\begin{array}{l}\text { Jumlah } \\
\text { Kalimat }\end{array}$ & $\begin{array}{c}\text { Ringkasan } \\
\text { (No. Kalimat) }\end{array}$ \\
\hline 1 & 4 & $1,5,6,7$ \\
\hline 2 & 4 & $1,4,6,11$ \\
\hline 3 & 8 & $1,2,3,4,7,8,9,13$ \\
\hline 4 & 7 & $1,2,3,4,8,10,11$ \\
\hline 5 & 3 & $1,7,10$ \\
\hline 6 & 5 & $1,4,7,12,13$ \\
\hline 7 & 3 & $1,3,6$ \\
\hline 8 & 2 & 1,10 \\
\hline 9 & 4 & $1,2,4,10$ \\
\hline 10 & 5 & $1,2,3,6,9$ \\
\hline 11 & 4 & $1,2,5,8$ \\
\hline 12 & 6 & $1,2,3,4,5,9$ \\
\hline 13 & 7 & $1,2,3,4,5,10,11$ \\
\hline 14 & 8 & $1,2,3,5,6,7,8,9$ \\
\hline 15 & 2 & 1,3 \\
\hline 16 & 7 & $1,3,4,6,7,8,12$ \\
\hline 17 & 4 & $1,2,3,5$ \\
\hline 18 & 7 & $1,3,4,5,8,10,17$ \\
\hline 19 & 4 & $1,2,5,6$ \\
\hline 20 & 6 & $1,6,7,9,12,14$ \\
\hline 21 & 9 & $1,3,4,5,9,10,11,12,13$ \\
\hline 22 & 4 & $1,2,3,6$ \\
\hline 23 & 4 & $1,3,4,9$ \\
\hline 24 & 8 & $1,2,3,5,10,12,13,16$ \\
\hline 25 & 3 & $1,7,11$ \\
\hline 26 & 5 & $2,3,5,6,7$ \\
\hline 27 & 8 & $1,2,3,4,6,7,9,10$ \\
\hline 28 & 4 & $1,2,7,8$ \\
\hline 29 & 6 & $2,7,8,9,13,15$ \\
\hline 30 & 3 & $1,2,5$ \\
\hline
\end{tabular}


Hasil perhitungan evaluasi diurutkan berdasarkan nilai recall, precision dan $f$ measure dari persentase yang tertinggi ke urutan terendah. Dari tabel tersebut menunjukkan bahwa berita ketiga belas memiliki nilai recall, precision dan $f$ measure persentase paling tinggi yaitu dengan nilai recall $100 \%$, precision $100 \%$ dan $f$-measure $100 \%$, sedangkan persentase terendah pada berita kedelapan dengan nilai recall $10 \%$, precision $50 \%$ dan f-measure $17 \%$. Berdasarkan hasil pengujian dan evaluasi ringkasan dapat diketahui bahwa hasil evaluasi antara ringkasan sistem dengan ringkasan manual menghasilkan nilai rata-rata recall sebesar $60 \%$, precision $77 \%$, dan f-measure sebesar $66 \%$. Pada hasil evaluasi antara ringkasan sistem dengan ringkasan manual, terdapat lima berita dengan nilai persentase f-measure rendah dibawah $50 \%$ yaitu berita nomor 9 dengan $46 \%$, berita nomor 5 dengan $46 \%$, berita nomor 6 dengan $31 \%$, berita nomor 15 dengan $25 \%$ dan nomor 8 dengan $17 \%$. Hal ini disebabkan oleh jumlah kalimat yang sama (overlap) adalah kecil atau sedikit sehingga menyebabkan hasil $f$-measurenya rendah. Jika semakin overlap kalimatnya yang terpilih banyak maka hasil dari f-measurenya tinggi.

\section{KESIMPULAN}

Kesimpulan yang didapat dari penelitian adalah : Metode maximum marginal relevance dapat digunakan untuk meringkas single dokumen secara otomatis dengan menggunakan judul artikel berita sebagai query, hasil dari uji coba yang dilakukan menghasilkan rata-rata recall $60 \%$, precision $77 \%$, dan $f$-measure $66 \%$ berdasarkan perbandingan sistem dengan ringkasan manual.

\section{SARAN}

Hasil ringkasan merupakan kalimat yang memiliki kemiripan dengan query dan berdasarkan urutan bobot MMR. Hasil perbandingan terhadap ringkasan manual terdapat beberapa artikel berita yang memiliki nilai $f$-measure rendah, karena query yang dimasukkan tidak menggambarkan isi, sehingga alimat yang terambil tidak sesuai urutan kalimat yang baik. Pengembangan lebih lanjut disarankan untuk menggunakan generator judul sebagai query untuk mendapatkan $f$-measure yang tinggi, kalimat ringkasan yang ditampilkan urut berdasarkan sistematika yang baik.

Tabel 18. Hasil Perbandingan Sistem dengan Ringkasan Manual

\begin{tabular}{|c|c|c|c|c|}
\hline $\begin{array}{c}\text { Nomor } \\
\text { berita }\end{array}$ & $\begin{array}{l}\text { Overlap } \\
\text { Kalimat }\end{array}$ & Recall & Precision & $\begin{array}{c}F- \\
\text { measure }\end{array}$ \\
\hline 1 & 4 & $80 \%$ & $100 \%$ & $89 \%$ \\
\hline 2 & 3 & $43 \%$ & $75 \%$ & $55 \%$ \\
\hline 3 & 7 & $88 \%$ & $88 \%$ & $88 \%$ \\
\hline 4 & 6 & $86 \%$ & $86 \%$ & $86 \%$ \\
\hline 5 & 3 & $30 \%$ & $100 \%$ & $46 \%$ \\
\hline 6 & 3 & $38 \%$ & $60 \%$ & $46 \%$ \\
\hline 7 & 2 & $50 \%$ & $67 \%$ & $57 \%$ \\
\hline 8 & 1 & $10 \%$ & $50 \%$ & $17 \%$ \\
\hline 9 & 3 & $33 \%$ & $75 \%$ & $46 \%$ \\
\hline 10 & 5 & $63 \%$ & $100 \%$ & $77 \%$ \\
\hline 11 & 4 & $80 \%$ & $100 \%$ & $89 \%$ \\
\hline 12 & 4 & $80 \%$ & $67 \%$ & $73 \%$ \\
\hline 13 & 7 & $100 \%$ & $100 \%$ & $100 \%$ \\
\hline 14 & 6 & $86 \%$ & $75 \%$ & $80 \%$ \\
\hline 15 & 1 & $17 \%$ & $50 \%$ & $25 \%$ \\
\hline 16 & 5 & $71 \%$ & $71 \%$ & $71 \%$ \\
\hline 17 & 3 & $75 \%$ & $75 \%$ & $75 \%$ \\
\hline 18 & 5 & $50 \%$ & $71 \%$ & $59 \%$ \\
\hline 19 & 3 & $60 \%$ & $75 \%$ & $67 \%$ \\
\hline 20 & 5 & $63 \%$ & $83 \%$ & $71 \%$ \\
\hline 21 & 6 & $75 \%$ & $67 \%$ & $71 \%$ \\
\hline 22 & 3 & $75 \%$ & $75 \%$ & $75 \%$ \\
\hline 23 & 3 & $60 \%$ & $75 \%$ & $67 \%$ \\
\hline 24 & 6 & $60 \%$ & $75 \%$ & $67 \%$ \\
\hline 25 & 3 & $43 \%$ & $100 \%$ & $60 \%$ \\
\hline 26 & 4 & $67 \%$ & $80 \%$ & $73 \%$ \\
\hline 27 & 5 & $71 \%$ & $63 \%$ & $67 \%$ \\
\hline 28 & 3 & $60 \%$ & $75 \%$ & $67 \%$ \\
\hline 29 & 4 & $40 \%$ & $67 \%$ & $50 \%$ \\
\hline 30 & 2 & $50 \%$ & $67 \%$ & $57 \%$ \\
\hline
\end{tabular}




\section{DAFTAR PUSTAKA}

Das and Martins. 2007. A Survey on Automatic Text Summarization. Language Technologies Institute Carnegie Mellon University

Erwin A.H., Muhammad. 2005. Sistem Pengidentifikasi Otomatis Pokok Kalimat Suatu Paragraf Dalam Dokumen Ekspositori Dengan Model Ruang Vektor. Laboratorium Pemrograman dan Informatika Teori. Yogyakarta: Jurusan Teknik Informatika Fakultas Teknologi Industri Universitas Islam Indonesia.

Firmin, T and M.J Chrzanowski. 1999. An Evaluation of Automatic Text Summarization System. The MIT Press: Cambrige

Golstein, Jade and Carbonell, Jaime. 1998. Summarization: Using MMR for Diversity Based-Reranking and Evaluating Summaries. Langauge Technologies Istitute. Carnegie Mellon University.

Golstein, Jade. 2008. Genre Oriented Summarization. Thesis. Pittsburgh: Language Technologies Institute School of Computing Carnegie Mellon University.

Garcia, E. 2006. The Classic Vector Space Model.

http://www.miislita.com/information-

retrieval-tutorial/. Diakses tanggal 25 Maret 2011.

Grossman, D., dan Ophir, F. 1998. Information Retrieval: Algorithm and Heuristics. Kluwer Academic Publisher.

Hovy, E. and Lin, C. Y. (1999). Automated text summarization in summarist. In Mani, I. and Maybury, M. T., editors, Advances in Automatic Text Summarization, pages 81-94. MIT Press

Husni, Muchammad dan Zaman, Badrus. 2005. Perangkat lunak Peringkas Dokumen Berbahasa Indonesia dengan Hybrid Stemming. Surabaya: Teknik Informatika Fakultas Teknologi
Informasi Institut Teknologi Sepuluh Nopember.

Jones, K.S, dan Galliers, J.R. 1996. Evaluating Natural Language Processing System : An Analysis and Review. New York: Springer.

Larson and Hearst. 2000. Computing Relevance, Similarity: The Vector Space Model. UC Berkeley. http://www.sims.berkeley.edu/courses/is2 02/f00/. Diakses tanggal 25 Maret 2011.

Mani, I. and Maybury. 1999. Advance in Automatic Text Summarization. The MIT Press: Cambrige.

Mani, Inderjeet. 2001. Summarization Evaluation: An Overview. The MITRE Corporation, W640 11493 Sunset Hills Road Reston, VA 20190-5214 USA.

Radlinski, Filip. 2008. Learning to Rank (part 2). In NESCAI 2008 Tutorial. Computer Science Cornell University. http://radlinski.org/papers/LearningToRa nk_NESCAI08.pdf. Diakses tanggal 20 Maret 2011.

Sartuni, Rasjid dkk. 1984. Bahasa Indonesia untuk Perguruan Tinggi. Jakarta: Nina Dinamika

Tala, Fadillah Z. 2003. A Study of Stemming Efects on Information Retrieval in Bahasa Indonesia. Institute for Logic, Language and Computation Universite itvan Amsterdam The Netherlands.

www.illc.uva.nl/publications/ResearchRe port/Mol-200302.text.pdf. Diakses tanggal 25 Februari 2011.

Xie, Shasha. 2010. Automatic Extractive Summarization Meeting Corpus. Dissertation. Dallas: The University of Texas at Dallas. 